\title{
Filozoficzne aspekty przyzwyczajenia
}

„Przyzwyczajenie to jakby druga natura”. Tych słów Cycerona nie sposób pominąć, zatrzymując się nad zagadnieniem przyzwyczajenia. Słowa te przeniknęły do naszej kultury na stałe i funkcjonują w formie przysłowia ludowego, nadając dużą wagę pojęciu przyzwyczajenia. Wbrew powszechnej tendencji do zawieszania sądów naukowych odnośnie do tego pojęcia warto się nad nim pochylić, chociażby ze względu na często pojawiające się w tradycji wątki, w których odgrywa ono rolę pierwszoplanową.

Zasadniczy cel artykułu stanowi ukazanie tego, że pojęcie przyzwyczajenia może być ujmowane jako istotna kategoria, co stawia je na uprzywilejowanej pozycji w dyskursie filozoficznym dążącym do opisu człowieka. Dla pełnego ukazania bogactwa podejmowanego zagadnienia przyzwyczajenie zostanie opisane wieloaspektowo, w perspektywie poszczególnych dyscyplin filozoficznych, w nawiązaniu do wybranych koncepcji. Analiza zmierza również do ukazania, że przyzwyczajenie jest pojęciem wielowymiarowym i może opisywać wiele sfer aktywności ludzkiej oraz łączyć się z ważnymi problemami natury filozoficznej, takimi jak chociażby kwestia postrzegania wartości.

\section{Definicja przyzwyczajenia ${ }^{1}$}

Należy wpierw ustalić kwestię rozumienia przyzwyczajenia. Sprawa doboru terminologii służącej do opisu i interpretacji tego pojęcia jest nader problematyczna,

${ }^{1}$ Dla przejrzystości wywodu autorka decyduje się na następujące rozróżnienie: przyjmuje, że w przypadku analizy czysto językowej, odnoszącej się m.in. do znaczeń słownikowych oraz reguł języka polskiego, wyraz ,przyzwyczajenie” będzie ujęty w cudzysłów. Natomiast zabieg ten będzie pomijany w odniesieniu do przyzwyczajenia jako pojęcia pierwotnego w przypadku analizy pojęciowej, za którą będą szły w parze pewne sformalizowane treści oraz w odniesieniu do samego zjawiska. 
gdyż rozważając słowo „przyzwyczajenie” od strony czysto językowej, bez trudu można dostrzec jego wieloznaczność. Różnorodność jego zastosowań wskazuje na uwikłanie wyrazu w wielość pól semantycznych, czego naturalną konsekwencją jest poszerzenie jego zakresu. Współczesne słowniki języka polskiego, zgodnie z intuicjami jego użytkowników, odnotowują słowo „przyzwyczajenie” w dwóch znaczeniach: jako nieposiadający liczby mnogiej rzeczownik pochodzący od czasownika „przyzwyczaić” lub jako rzeczownik posiadający liczbę mnogą, którego znaczenie wyrażają eksplikacje takie, jak: „nawyk”, „zwyczaj”, „nałóg”2. Wydaje się, że pierwsza forma, pochodząca od czasownika, pozbawiona liczby mnogiej, może nazywać sam proces przyzwyczajania się. Od strony językowej takie rozumienie wspiera fakt, że nazwy procesów pozbawione są liczby mnogiej. Natomiast druga forma może zostać potraktowana jako nazwa efektu tego procesu. Wówczas zarówno „nawyk”, „nałóg”, jak i „zwyczaj” można uznać za synonimy słowa „przyzwyczajenie” w drugim z wymienionych znaczeń, traktowanego jako pewien efekt końcowy trwającego w czasie procesu. Dlatego też przejrzystość wywodu wymaga dookreślania tego, czy w danym przypadku przez słowo to rozumiany jest proces, czy też jego efekt.

W związku z tym autorka proponuje przyjęcie szerokiej definicji kluczowego słowa, w myśl której przyzwyczajenie stanowi proces lub funkcjonujący w formie psychofizycznego wzorca efekt procesu, któremu - ze względu na długotrwałość lub powtarzalność - towarzyszy zmniejszenie uwagi względem poziomu początkowego. Wydaje się, że taka definicja jest na tyle pojemna, by objąć swym zakresem przyzwyczajenie w różnych jego aspektach. Ponadto autorka zakłada za rodzimym językoznawcą, Maciejem Grochowskim, że słowo „przyzwyczajenie” jest bardziej pojemne niż wyraz „nawyk”3. Uważa także, iż można potraktować pojęcie nawyku jako podzbiór pojęcia przyzwyczajenie, niewyczerpujący jego pełnego sensu.

\section{Przyzwyczajenie jako kategoria filozoficzna}

Istotnym pojęciem dla niniejszych rozważań jest pojęcie „kategorii”. Według Barbary Skargi historia myśli ludzkiej ujawnia tendencję do organizowania się, w ramach podejmowanych problemów badawczych, wokół pewnych pojęć. Pojęcia te określa jako kategorie. Dlatego też przez kategorie rozumie ona „pojęcia podstawowe

${ }^{2}$ Uniwersalny stownik języka polskiego, red. S. Dubisz, t. 3, Warszawa 2003, s. 1147; Stownik wspótczesnego języka polskiego, red. B. Dunaj, Warszawa 1996, s. 916.

${ }^{3} \mathrm{M}$. Grochowski, O strukturze pojęć „przyzwyczajenie”, „,nawyk”, „,nałóg”. Rozważania semantyczne, [w:] Etudes de linguistique romane et slave, red. W. Banyś, L. Bednarczuk, K. Bogacki, Kraków 1992, s. 243-252. 
dla rozważań intelektualnych danego okresu historycznego, dość powszechnie występujące, ale bynajmniej niekonieczne"4.

Porządkując myśli wspomnianej autorki można dostrzec, że po pierwsze, kategoria jest wypadkową uogólnienia danych problemów i zagadnień pojawiających się w historii myśli. Po drugie, kategoria jest czymś powszechnie występującym, ale nie jest obarczona klauzulą konieczności ani niezmienności. Po trzecie, kategorie, z racji powszechności, mają duży zasięg, w związku z tym wyznaczają i organizują pewne pole teoretyczne. Po czwarte, poza wyznaczeniem terytorium badawczego kategorie same stanowią jego rdzeń i zarazem główny przedmiot. Po piąte, z racji wysokiego stopnia ogólności kategorie często uwikłane są w siatkę pojęć z nimi współwystępujących ${ }^{5}$. Wydaje się, że przyzwyczajenie może spełniać powyższe postulaty. Problem można rozważyć na gruncie kilku subdyscyplin filozoficznych.

\section{Przyzwyczajenie jako kategoria etyczna}

Określając obszar zainteresowań badań etycznych, zwraca się uwagę na opis elementarnych składników moralności, które są na tyle pierwotne, że nie można dla nich znaleźć wcześniejszych od nich przyczyn, a za których pomocą wyjaśniane są inne składniki ${ }^{6}$. Wydaje się, że przyzwyczajenie może być respektowane jako jeden z takich składników lub też jako mechanizm wspierający ich funkcjonowanie. Na poparcie tej tezy zostaną zaprezentowane wybrane stanowiska z tradycji myśli etycznej.

Niewątpliwie jedną z ważniejszych koncepcji stanowi teoria cnót Arystotelesa. Prezentując swój podział cnót, przyjmuje on, że dwie główne kategorie stanowią cnoty dianoetyczne, czyli teoretyczne, posiadające charakter rozumowy, oraz - szczególnie interesujące dla niniejszych rozważań - cnoty etyczne, czyli praktyczne, wyrabiane przez przyzwyczajenie.

Dla Arystotelesa przyzwyczajenie pełni istotną rolę - jest ukazane jako trwała dyspozycja do postępowania w sposób moralnie pożądany (efekt procesu przyzwyczajenia) oraz jako proces ukierunkowany na wytworzenie dyspozycji (proces przyzwyczajenia). Gdyby nie zdolność do przyzwyczajania się do danych zachowań, podmiot moralny nie byłby w stanie wyrobić w sobie cnoty, gdyż nie jest ona dana ludziom z natury, wrodzona. W Etyce nikomachejskiej filozof pisze:

\footnotetext{
${ }^{4}$ B. Skarga, Granice historyczności, Warszawa 2005, s. 107n.

${ }^{5}$ Tamże, s. 109n.

${ }^{6}$ T. Ślipko, Zarys etyki ogólnej, Kraków 2009, s. 35n.
} 
[Zalet] etycznych natomiast nabywa się dzięki przyzwyczajeniu [...]. Więc cnoty nie stają się udziałem naszym ani dzięki naturze, ani wbrew naturze, lecz z natury jesteśmy zdolni do ich nabywania, a rozwijamy je w sobie dzięki przyzwyczajeniu?

Znaczenie cnoty jest dla myśliciela istotne, gdyż to właśnie ona decyduje o postępowaniu w sposób właściwy lub niewłaściwy ${ }^{8}$. Dlatego też Arystoteles podkreśla wagę przyzwyczajania się w wychowaniu moralnym, gdyż powoduje ono trwałe konsekwencje dla podmiotów moralnych. To, do jakiego sposobu postępowania przyzwyczai się człowiek za młodu, jest istotne, gdyż „zależy od tego bardzo wiele, a raczej wszystko"9. Arystoteles podkreśla ważność ćwiczenia się w cnotach, podaje więc wskazówki dla osób odpowiedzialnych za krzewienie moralnych zachowań wśród swych wychowanków. Wychowawcy winni przez przyzwyczajenie przygotowywać swoich uczniów do pracy nad sobą, jeśli chcą, by wychowanie przyniosło efekty ${ }^{10}$.

Dla Arystotelesa jakość życia moralnego jest ściśle powiązana nie tylko z rozwojem indywidualnym, ale także ze sferą publiczną. Akcentuje więc rolę przyzwyczajenia w kształtowaniu sfery społeczno-politycznej, bowiem może ono służyć jako narzędzie wychowania obywateli ${ }^{11}$.

W koncepcji cnót Arystotelesa można również odnaleźć znamienną zasadę, tzw. zasadę złotego środka, w której kluczową rolę odgrywa idea umiaru ${ }^{12}$. Umiar jest z kolei dyktowany przez rozum. Arystoteles lokalizuje cnoty po stronie rozumu praktycznego, wyrastającego z doświadczenia, gdzie kluczową rolę odgrywa przyzwyczajenie. Zwraca na to uwagę Paweł Kłoczowski: „Cnota rozumu praktycznego zakorzeniona jest zatem w przyzwyczajeniu"13. Dlatego Arystotelesowskie przyzwyczajenie jest konieczne dla kształtowania podmiotu moralnego.

Cnota wyrabiana przez przyzwyczajenie stoi w centrum etycznego systemu Arystotelesa. Jest to ściśle związane z jego pojmowaniem ludzkiego dążenia do szczęścia. W koncepcji tej celem życia jest szczęście i najwyższe dobro ${ }^{14}$. Szczęście uzależnione jest od dobrego życia, dobre życie zależne jest od tego, czy podmiot moralny żyje w sposób cnotliwy. Przyzwyczajenie w sposób bezpośredni rzutuje więc na kształtowanie dobra, a w pośredni - na kształtowanie szczęścia.

${ }^{7}$ Arystoteles, Etyka nikomachejska, thum. D. Gromska, [w:] tenże, Dzieła wszystkie, t. 5, Warszawa 2002, s. 103 n.

${ }^{8}$ Tamże, s. 110 n.

${ }^{9}$ Tamże, s. $104 \mathrm{n}$.

${ }^{10}$ Tamże, s. 296n.

${ }^{11}$ Tamże, s. 104, 296.

${ }^{12}$ Tamże, s. 113.

${ }^{13} \mathrm{P}$. Kłoczowski, Rola przyzwyczajeń w życiu moralnym i politycznym - konfrontacja Arystotelesa i Kanta, [w:] Rozum a porządek społeczny, red. J. Miklaszewska, Kraków 2002, s. 153.

${ }^{14}$ Arystoteles, Etyka wielka, thum. W. Wróblewski, [w:] tenże, Dzieła wszystkie, dz. cyt., s. 316n. 
Arystoteles ujmuje przyzwyczajenie w dwóch aspektach. Z jednej strony, traktuje on przyzwyczajenie jako proces zmierzający do kształtowania moralności, natomiast $\mathrm{z}$ drugiej strony, utożsamia je z utrwaloną tendencją do postępowania w sposób moralnie dobry, gdyż cnota stanowi według niego trwałą dyspozycję. Tylko cnocie człowiek może zawdzięczać to, że „staje się dobry i [...] spełniać będzie należycie właściwe sobie funkcje"

Zagadnienie dyspozycji uwikłane jest w wiele problemów natury językowej. Greckim terminem oznaczającym cnotę jest słowo hexis, jego łacińskim odpowiednikiem zaś - habitus ${ }^{16}$, które używane jest w odniesieniu do Arystotelesa przez Tomasza z Akwinu, komentatora myśli Arystotelesowskiej. W dokonanym przez Danielę Gromską przekładzie dzieł Arystotelesa hexis jest tłumaczone jako „dyspozycja”. Natomiast słowo habitus odnosi się w języku polskim do terminów takich, jak „dyspozycja” lub „sprawność”, choć za konkurencyjne dla tego tłumaczenia uznaje się słowo „nawyk” ${ }^{17}$. Woroniecki, wybitny przedstawiciel dwudziestowiecznej etyki, zabierający ważny głos w tej dyskusji, przyznaje prymat tłumaczeniu habitus przez „sprawność” 18 . Wyliczając długą listę różnic między sprawnością i nawykiem, utożsamianym przez niego z przyzwyczajeniem, autor ten uznaje, że do rezygnacji z odniesienia habitus do nawyku przyczynił się Akwinata.

Dla św. Tomasza cnota to dyspozycja - habitus ${ }^{19}$. Stanowi ona wewnętrzną zasadę ludzkich aktów. Podobnie jak u Arystotelesa, dyspozycja jest wytwarzana poprzez powtarzanie pewnych czynności, czyli przez przyzwyczajenie się do ich wykonywania. Fundamentem powstania cnoty moralnej jest dla niego pragnienie, które powoduje, że w człowieku rozwijana jest naturalna skłonność do działania. Myśliciel odstępuje od możliwości ujmowania cnót moralnych w abstrahowaniu od woli pragnienia. Przyzwyczajenie rozumiane jako proces stanowi dla niego środek do usprawniania dyspozycji, nie zaś źródło, z którego rodzi się cnota. „Podobnie też dzięki wielokrotnie dokonywanym czynnościom rośnie dyspozycja" ${ }^{20}$.

W sprawach moralnych Akwinata jest raczej skłonny podkreślać możliwość ciągłego dokonywania wyboru kierowanego przez pragnienie postępowania w określony sposób ${ }^{21}$. Podkreślając rolę pragnienia w kształtowaniu cnót, św. Tomasz nie wyklucza przy tym udziału innych władz, takich jak roztropnośćc ${ }^{22}$, która stanowi dla niego sprawność rozumu - jest w jego klasyfikacji kardynalną

\footnotetext{
${ }^{15}$ Arystoteles, Etyka nikomachejska, dz. cyt., s. 111.

${ }^{16}$ Zob. W. Galewicz, Wstęp tłumacza, [w:] św. Tomasz z Akwinu, Traktat o cnotach, thum. W. Galewicz, Kęty 2006, s. 11.

${ }^{17}$ Zob. tamże, s. 11n; T. Ślipko, Zarys etyki..., dz. cyt., s. 397.

${ }^{18}$ J. Woroniecki, Katolicka etyka wychowawcza, t. 1, Lublin 1986, s. 333-337.

${ }^{19}$ św. Tomasz z Akwinu, Traktat ..., dz. cyt., s. 61n, 118, 120n, 123.

${ }^{20}$ Tamże, s. 102.

${ }^{21}$ Tamże, s. 150n.

${ }^{22}$ Tamże, s. 217.
} 
cnotą rozumu praktycznego ${ }^{23}$. Dzięki temu widać wyraźnie, że działanie ma charakter rozumny.

Rozum jest zasadą szlachetniejszą aniżeli dyspozycja moralnej cnoty, wytwarzana we władzy pragnienia wskutek przyzwyczajenia się do odpowiednich czynności ${ }^{24}$.

W tym sensie większość tomistów uważa, że cnotę moralną należy postrzegać zarówno jako sprawność rozumu, jak również jako sprawność wolii ${ }^{25}$. Natomiast według Tadeusza Ślipki tę cnotę należy rozpatrywać przede wszystkim jako zdolność woli człowieka. Etyk ten wskazuje na to, że cnoty są ukierunkowane na dobra moralne. Jeśliby roztropność, jako sprawność rozumu, została skierowana w stronę celów niegodziwych, i tak ostatecznie rozstrzygająca byłaby wola człowieka jako sprawność ukierunkowująca człowieka na świadomą realizację dóbr. Zgodnie $\mathrm{z}$ koncepcją tego autora w sferze moralności kluczowa jest więc wola spełniania aktów dobrych. Można dostrzec, że przyzwyczajenie w tej interpretacji ustępuje zarówno rozumowi, jak i woli.

Dla Akwinaty rozum był szlachetniejszy od dyspozycji moralnej cnoty, natomiast u Immanuela Kanta „rozkaz rozumu władający w sferze moralności” wyznaczał działania moralne ${ }^{26}$. Jednakże ten drugi myśliciel całkowicie oddzielał przyzwyczajenie od tworzenia cnót, dlatego że „nie da się cnoty wyjaśnić jako wprawy”27. Habitus nie stanowi dla Kanta odpowiedniej kategorii do wyjaśnienia cnoty, gdyż wprawa jest przyzwyczajeniem stanowiącym ,konieczność subiektywno-praktyczną”. Natomiast cnota wymaga ponawiania decyzji o wypełnieniu obowiązku, czego nie jest w stanie zapewnić mechaniczne, wyćwiczone działanie. Jego zdaniem „moralna siła wypełniania obowiązku”, motywowana przez „rozkaz rozumu”, określa moralność. Subiektywne przyzwyczajenie jest dla niego niewystarczające.

Cnota jest to taka moralna siła [Stärke] wypełniania obowiązku, która nigdy nie stanie się przyzwyczajeniem, lecz zawsze od nowa, źródłowo wypływać będzie ze sposobu myślenia ${ }^{28}$.

Przyzwyczajenie występuje u Kanta również w nieco innym aspekcie - jako pewien stan powodujący przytępienie uwagi w przypadku wystawienia zmysłów

${ }^{23}$ Zob. A. Anzenbacher, Wprowadzenie do etyki, tłum. J. Zychowicz, Kraków 2008, s. 145; por. T. Ślipko, Zarys etyki..., dz. cyt., s. 396-398.

${ }^{24}$ św. Tomasz z Akwinu, Traktat..., dz. cyt., s. 90.

${ }^{25}$ Zob. T. Ślipko, Zarys etyki..., dz. cyt., s. 397n.

${ }^{26}$ I. Kant, Antropologia w ujęciu pragmatycznym, thum. E. Drzazgowska, P. Sosnowska, Warszawa 2005, s. 41.

${ }^{27}$ Tamże, s. 39.

${ }^{28}$ Tamże. 
na jednakowe wrażenie, trwające przez dłuższy czas ${ }^{29}$. Warto zauważyć, że Kant odróżnia przyzwyczajenie (consuetudo) będące stanem, który „pozwala nam łatwiej znieść zło" i zarazem ,utrudnia uświadomienie i przypomnienie sobie doznanego dobra" 30 , od - stanowiącego dla Woronieckiego ekwiwalent przyzwyczajenia - nawyku (assuetudo). Nawyk jest według niego ,wewnętrznym fizycznym przymusem". Przyrównuje on nawyki do instynktownego działania zwierząt, gdyż „nazbyt ujawniają one zwierzę w człowieku”31. Co prawda Kant stwierdza, że niektóre działania oparte na nawyku są dopuszczalne, choć na ogół są według niego nacechowane silnie pejoratywnie, gdyż ograniczają człowieka i narażają go na śmieszność. Bezmyślne powtarzanie czynności pozbawia nawykowe działanie wartości dobra. Wartość taka może być skojarzona tylko z refleksyjnością, a tę cechę nawyk unieważnia.

Paweł Kłoczowski wskazuje na element różniący etykę Arystotelesa i Kanta, wynikający z odmienności w rozumieniu przez nich przyzwyczajenia. Rozróżnia on dwa sposoby rozumienia tego pojęcia ${ }^{32}$. Pierwszy opisuje przyzwyczajenie jako „sprawność" i takie rozumienie uznaje za charakterystyczne dla etyki Arystotelesa, natomiast drugi, przyzwyczajenie jako „nawyk”, za rozumienie typowe dla etyki Kanta. Kłoczowski wskazuje na to, że podobieństwo między nawykiem i sprawnością wynika ze zbieżności tkwiących w ich powstawaniu, które można ująć jako efekt długotrwałego i wielokrotnego powtarzania czynności. Wydaje się zatem, że nawyk i sprawność stanowią odmienne efekty zachodzącego w czasie procesu przyzwyczajenia.

Konstruując swoje stanowisko, dotyczące dwóch aspektów pojęcia przyzwyczajenie, Kłoczowski przytacza listę różnic między nawykiem a sprawnością, sformułowaną przez Woronieckiego ${ }^{33}$. Według tego ostatniego nawyk można scharakteryzować jako nieświadomą czynność mechaniczną, przebiegającą w sposób niezależny od woli oraz pozbawiający wykonawcę satysfakcji. Sprawności natomiast zawsze towarzyszy świadomość i ukierunkowanie na cel. Ponadto uzależniona jest ona od woli wykonawcy oraz cechuje się większą elastycznością. Kłoczowski wyjaśnia przyczyny powstania tej dychotomii. W systemie Arystotelesa ważną rolę odgrywają skłonności do dobrego wykonywania powierzonego zadania, które - odpowiednio ukierunkowane - mogą wspierać spełnianie obowiązków. Łatwość wykonywania działań może świadczyć o wadze doskonałości moralnej. Natomiast u Kanta wartość czynu mierzona jest wysiłkiem włożonym w walkę ze skłonnościami czy inklinacjami natury - czyn jest dziełem powinności. Filozof ten ostro odgranicza

\footnotetext{
29 Tamże, s. 42.

${ }^{30}$ Tamże.

${ }^{31}$ Tamże.

${ }^{32}$ P. Kłoczowski, Rola przyzwyczajeń..., dz. cyt., s. 156.

${ }^{33}$ Tamże, s. 157.
} 
skłonność od obowiązku. Na tej podstawie Kłoczowski wprowadza dwojakie rozumienie przyzwyczajenia.

Przyzwyczajenie, zdaniem Kłoczowskiego, stanowi naturalne i podstawowe narzędzie wspierające rozwój moralności. Jest to przede wszystkim związane z faktem, że skłonności mogą zostać ukierunkowane w trakcie procesu wychowania moralnego dzięki utrwaleniu danych sprawności w sposób unikający kolizji z powinnościami ${ }^{34}$.

Blaise Pascal, mówiąc o cnotach, spogląda na nie przez pryzmat zarówno nawyków, jak i procesu przyzwyczajenia. Stwierdza, że „człowiek przyzwyczaja się do cnót wewnętrznych za pomocą tych zewnętrznych nawyków"35. W swych pismach formułuje myśl, że nawyki tworzą ,automat”, przy czym ,automat” ten - można by rzec - współpracuje z duchem i pociąga go do działania. Jak twierdzi Pascal, „jesteśmy tyleż automatem, co duchem" ${ }^{36}$. Z kolei David Hume, dla którego nawyk tożsamy jest z przyzwyczajeniem i stoi w centrum systemu poznawczego, konsekwentnie akcentując jego rolę również w sferze moralności, twierdzi, że należy sobie wytworzyć „odpowiednie nawyki i zobowiązać się do unikania występku i do wierności cnocie" ${ }^{37}$. Natomiast Benjamin Franklin wskazuje na dwustronność nawyków. Według niego ,złe w skutkach nawyki muszą być przełamane, a dobre nabyte i utrwalone" ${ }^{38}$. To właśnie ma doprowadzić człowieka do „osiągnięcia doskonałości moralnej”.

Według Franza Brentano wiele usankcjonowanych przez etykę poglądów powstało właśnie wskutek procesu przyzwyczajenia, nie zaś dzięki „logicznej zasadności” czy chrześcijańskiemu etycznemu ideałowi poszanowania Boga i bliźniego ${ }^{39}$. Zauważa, że nieraz w dziejach ludzkości przyzwyczajenie służyło „prymitywnej tresurze" ludzi słabszych. Stanowiło ono narzędzie stosowane przez ludzi lepiej sytuowanych, nastawionych egoistycznie. Przyzwyczajenie „w takiej niewolniczej duszy zaczynało działać jako ślepa potężna siła, nakazująca «powinieneś», jakby stanowiła objawienie natury dobra i zła" ${ }^{40}$. Dla tego myśliciela zachowania oparte na przyzwyczajeniu ,ślepym na pierwotne cele” pozbawione były „udziału etycznych zasad poznawczych". Dlatego też Brentano przestrzega przed podejmowaniem tego rodzaju działań w tworzeniu prawdziwej etyki. Na zbieżność między przyzwyczajeniem a tresurą wskazuje również Henri Bergson.

W dziele Dwa źródła moralności i religii Bergson wprowadza swój podział na dwa rodzaje moralności, tj. moralność zamkniętą i otwartą ${ }^{41}$. Mówi także o dwóch

\footnotetext{
${ }^{34}$ Tamże, s. 157n.

${ }^{35}$ B. Pascal, Myśli, thum. T. Żeleński (Boy), Warszawa 1983, s. 277.

${ }^{36}$ Tamże, s. 187.

${ }^{37}$ D. Hume, Badania dotyczące zasad moralności, tłum. M. Filipczuk, T. Tesznar, Kraków 2005, s. 7.

${ }^{38}$ B. Franklin, Żywot własny, tłum. J. Stawiński, Warszawa 1961, s. 107.

${ }^{39}$ F. Brentano, O źródle poznania moralnego, thum. C. Porębski, Warszawa 1989, s. 43-45.

${ }^{40}$ Tamże, s. 43.

${ }^{41}$ Zob. F. Copleston, Historia filozofii, thum. B. Chwedeńczuk, t. 9, Warszawa 1991, s. 202-212.
} 
sposobach, którymi mogą posługiwać się wychowawcy kształtujący moralność swoich podopiecznych. Pierwszym sposobem jest droga tresury, oparta na tworzeniu przyzwyczajeń, drugim zaś - droga mistyczności ${ }^{42}$. Filozof ten kładzie nacisk na duchowy aspekt wychowania, połączony z naśladowaniem osoby. Przyzwyczajenia, w myśl jego koncepcji, stanowią wykształcony drogą ewolucji „quasi-inteligentny mechanizm" służący „podtrzymywaniu życia społecznego" "33. Mechanizm ten posiada charakter zachowawczy i zastępuje instynkt. Bergson wprowadza również do swoich rozważań moralnych pojęcie „aspektu statycznego moralności”44. Charakteryzuje go jako „zespół przyzwyczajeń”, kategorię niższą hierarchicznie od inteligencji; działa on w sposób zbliżony do instynktów zwierzęcych. Moralność wspartą na przyzwyczajeniach Bergson nazywa „moralnością duszy zamkniętej”. Jest to moralność obowiązku, która powstaje w odpowiedzi na poczucie nacisku społecznego, wobec którego jednostka wykształca w sobie obowiązek społeczny ${ }^{45}$. Istotę tego obowiązku określa mianem „całości powinności”:

Ujawnia się tu siła, którą nazwaliśmy całością powinności: jest to zagęszczony ekstrakt, kwintesencja tysiąca poszczególnych przyzwyczajeń, których nabraliśmy, by podporządkować się tysiącom szczegółowych wymagań życia społecznego ${ }^{46}$.

Moralność obowiązku wiąże się zatem z prostym przestrzeganiem kodeksów będących narzędziem służącym do utrzymania spójności społeczeństw. Przeciwieństwem moralności obowiązku jest drugi typ moralności, oparty na wartościach - jego zdaniem - wyższych. Ów typ Bergson opisuje jako ,aspekt dynamiczny moralności”, który łączy z dążeniem, intuicją i emocją; czymś, co w założonej hierarchii zajmuje miejsce na szczeblu wyższym niż inteligencja ${ }^{47}$. Tę moralność nazywa „moralnością duszy otwartej".

Moralność zamknięta, oparta na przyzwyczajeniach, jest tylko „społeczna”, a nie „ludzka” jak moralność otwarta ${ }^{48}$. Dlatego rozum, mimo iż nie pełni roli źródła w kształtowaniu moralności, pośredniczy między dwoma typami moralności i ,usiłuje w zamkniętą moralność wprowadzić powszechność, a w otwartą obowiązek", mówiąc słowami Fredericka Coplestona ${ }^{49}$. W tym sensie rola rozumu, choć nie jest całkowicie zdyskredytowana, zostaje znacząco ograniczona.

\footnotetext{
${ }^{42}$ H. Bergson, Dwa źródła moralności i religii, tłum. P. Kostyło, K. Skorulski, Kraków 1993, s. 100n.

${ }^{43}$ Tamże, s. 60.

${ }^{44}$ Tamże, s. 68.

${ }^{45}$ Zob. F. Copleston, Historia ..., dz. cyt., s. 204.

${ }^{46}$ H. Bergson, Dwa źródta ..., dz. cyt., s. 29.

${ }^{47}$ Tamże, s. 68.

${ }^{48}$ Tamże, s. 41.

${ }^{49}$ F. Copleston, Historia ..., dz. cyt., s. 207.
} 
Należy sformułować kilka uwag poświęconych Bergsonowskiemu rozumieniu pojęcia przyzwyczajenia. Przede wszystkim pojęcie to, jak się zdaje, u tego filozofa ukazane jest w kilku aspektach. Zdarza się, że odnosząc się do przyzwyczajenia, opisuje on czynności motoryczne ${ }^{50}$. Przyzwyczajenia można w tym sensie uznać za elementarne nawyki (jak w typologii Woronieckiego przyjętej przez Kłoczowskiego). Bergson często ucieka się również do przyrównania przyzwyczajenia do instynktu czy może raczej do skłonności ${ }^{51}$. Czasem natomiast traktuje przyzwyczajenie jako pewien wzorzec o charakterze społecznym, do którego ukształtowania może prowadzić wychowywanie ${ }^{52}$. Niekiedy filozof zdaje się traktować przyzwyczajenie jako pewien stan psychiczny ${ }^{53}$, innym razem porównuje je zaś do postawy ${ }^{54}$. Przyzwyczajenie w systemie Bergsona jest niewątpliwe wieloaspektowe i złożone, choć umiejscowione na najniższym szczeblu proponowanej przez niego struktury moralności.

Na podstawie powyższych stanowisk można stwierdzić, że przyzwyczajenie może wchodzić w zakres zainteresowań etycznych, gdyż jest ujmowane jako elementarny składnik moralności lub jako mechanizm wspierający albo utrudniający kształtowanie innych składników tego rodzaju. Przyzwyczajenie ujawniało się przede wszystkim jako pojęcie wieloaspektowe. Było opisywane głównie w odniesieniu do sfery zachowań rozumianych jako nawyki i sprawności, choć ujmowano je również jako skłonność, dyspozycję, wzorzec społeczny czy stan psychiczny. Zawsze jednak w istotny sposób wiązało się z problemem ludzkiego dążenia do osiągania dobra, nawet jeśli było rozpatrywane jako subiektywistycznie rozumiana przeszkoda. W związku z tym, że wpływ przyzwyczajenia na kształtowanie moralności jest często akcentowany, można dowieść, że stanowi ono ważną kategorię etyczną.

\section{Przyzwyczajenie jako kategoria epistemologiczna}

Rozważania epistemologiczne skupione są wokół szeroko pojętej problematyki poznania oraz jego źródeł. Jak zauważa Jan Woleński, „filozofowie uznali właśnie zmysły i rozum za podstawowe elementy ludzkiego instrumentarium poznawczego"s5. Dlatego też ważnymi dla jej rozstrzygnięć kategoriami są rozum i zmysły, ujmowane jako opozycyjne władze poznawcze, oraz zakorzenione w nich poznanie. Opozycyjne podejścia do źródeł poznania uwikłane są w wielowiekowy spór znany pod nazwą

\footnotetext{
${ }^{50}$ H. Bergson, Dwa źródta ..., dz. cyt., s. 27.

${ }^{51}$ Tamże, s. 32, 99.

52 Tamże, s. 16.

${ }^{53}$ Tamże, s. 25, 37.

${ }^{54}$ Tamże, s. 29.

${ }^{55}$ J. Woleński, Epistemologia, Warszawa 2007, s. 417.
} 
„empiryzm versus racjonalizm”. Problematyka przyzwyczajenia może dotykać sedna tego sporu, gdyż ściśle związana jest z akcentowaniem roli doświadczenia zmysłowego w kształtowaniu ludzkiego poznania.

Na temat związku władz poznawczych z przyzwyczajeniem - zarówno jako efektem, jak i procesem - można znaleźć liczne wzmianki w systemach filozoficznych, począwszy od sformułowanego przez Platona w księdze VII Państwa mitu jaskini, w której autor wielokrotnie mówi o przyzwyczajeniu się zmysłu wzroku do ciemności ${ }^{56}$, poprzez średniowieczne teorie podkreślające jego znaczenie, a skończywszy na nowożytnych stanowiskach przypisujących mu kluczową rolę w poznawaniu świata zewnętrznego.

W pismach Piotra Abelarda można znaleźć kilka wzmianek na temat wpływu przyzwyczajenia na ludzkie poznanie. Według tego filozofa poznanie bierze początek w zmysłach, a następnie zostaje poddane analizie rozumowej. Mimo iż rola zmysłów w epistemologii Abelarda jest istotna, rozum jest dla niego zdolnością ułatwiającą duszy poznanie i odróżnienie natury rzeczy. Odgrywa on ważną rolę w jego systemie. Wrażenie zmysłów rozumie jako ,spostrzeżenie materialnych przedmiotów”, „działanie duszy” skierowanej na świat ${ }^{57}$. Zmysły zaś poddane są działaniu siły przyzwyczajenia. W dużym stopniu determinuje ono poznanie, ponieważ dane pochodzące ze zmysłów są uzupełniane o detale dostrzeżone uprzednio, a nieobecne bezpośrednio. Dla niego wyobrażenie, stanowiące produkt poznania, jest tylko przypomnieniem wrażenia i nie łączy się z refleksją rozumu. Natomiast wyobraźnia, poddana wpływowi przyzwyczajenia, jest uzupełniana elementami nieobecnymi w naturze rzeczy, o której ludzie myślą i do których przyzwyczaili się dzięki doświadczeniu zmysłów. Przyzwyczajenie w tym sensie determinuje akty poznawcze, gdyż zmysły, odbierając po wielokroć konkretną daną pochodzącą z doświadczenia, przyzwyczajają się do tej konkretnej danej.

Jak się okazuje, wiązanie przyzwyczajenia z funkcjonowaniem wyobraźni i zmysłów jest w filozofii rzeczą dość popularną. Julien Offray de La Mettrie zauważa pozytywne działanie przyzwyczajenia na wyobraźnię. Według niego wyobraźnię należy przyzwyczaić do panowania nad jej porywami - wówczas zdolna będzie do pełnego oglądu przedmiotu i zarazem do podjęcia pełniejszego procesu rozumowania ${ }^{58}$. Wbrew swym mechanicystycznym upodobaniom filozof ten nie odrzuca całkowicie opisu funkcji umysłowych. Wyobraźnia stanowi dla niego kluczową kategorię umysłową. Dlatego też przyzwyczajenie, które rzutuje na to, czy podmiot zatrzyma się wyłącznie na odbieraniu wrażeń, czy też przejdzie do badania ich prawdziwości lub podobieństwa, stanowi ważny element poznania ${ }^{59}$.

${ }^{56}$ Platon, Państwo, tłum. W. Witwicki, Kęty 2003, s. 222, 224, 225, 227.

${ }^{57}$ P. Abelard, Rozprawa o pojęciach ogólnych, tłum. L. Jachimowicz, [w:] tenże, Rozprawy, Warszawa 2001, s. 631.

${ }^{58}$ J. O. de La Mettrie, Człowiek-maszyna, tłum. S. Rudniański, Warszawa 1953, s. 45n.

${ }^{59}$ Tamże, s. 44. 
Wpływ przyzwyczajenia na zmysły, wyobraźnię oraz poznanie zauważa również Hume. Stwierdza on, że wszelkie poznanie ma swe źródło w doświadczeniu zmysłowym, dlatego też elementarnymi jednostkami jego ,umysłowej geografii" ${ }^{0}$ są „,impresje”, tj. wrażenia, oraz wywodzące się z nich „idee”, tj. myślíi ${ }^{61}$. Według niego ludzkie poznanie ogranicza się do wiedzy o ideach oraz pierwotnego wobec niej bezpośredniego doświadczenia ${ }^{62}$. Dzięki impresjom można ująć bezpośrednio obiekty ze świata zewnętrznego. Natomiast idee, stanowiące kopie wrażeń, pojawiają się w pamięci lub wyobraźni. Rola pamięci koncentruje się głównie wokół przechowywania i porządkowania wrażeń, dopiero w wyobraźni dokonuje się asocjacja idei ${ }^{63}$. Wyobraźnia „nie jest nieskrępowana" ${ }^{64}$, dlatego też można w niej odnaleźć powiązania między ideami. Filozof ten mówi o istnieniu tylko trzech zasad wiązania idei. Są to ,podobieństwo, styczność w czasie lub przestrzeni oraz przyczyna lub skutek" ${ }^{\prime \prime}$. Ten ważny punkt w systemie Hume'a stanowi podstawę wiedzy o ideach.

Myśliciel akcentuje wagę zasady przyczynowo-skutkowego kojarzenia idei ${ }^{66}$, twierdząc, że na niej opierają się wszelkie procesy rozumowe dotyczące faktów. Samo rejestrowanie powiązań przyczynowo-skutkowych pochodzi zaś z doświadczenia zmysłowego ${ }^{67}$. Zdaniem Hume'a bez doświadczenia rozum ,nie jest w stanie wyciągnąc żadnych wniosków dotyczących rzeczywistego istnienia i faktów"68. Również nie bez znaczenia są pozostałe zasady. Zasada podobieństwa wraz z zasadą przyczynowo-skutkową wpływają na ludzkie oczekiwanie podobnych skutków po podobnych przyczynach ${ }^{69}$. Zasada styczności, związana z regularnym występowaniem ciągu jednorodnego doświadczenia danego rodzaju, wpływa na poczucie pewności oraz zaufania do poszczególnych wypadków.

Wiązanie idei drogą kojarzenia jest ufundowane na pewnej zasadzie stanowiącej „tajemną siłę"70 , która jest na stałe wpisana w naturę człowieka. Zasada ta umożliwia wyciąganie wszelkich wniosków z doświadczenia bez konieczności odwoływania

${ }^{60}$ D. Hume, Badania dotyczące rozumu ludzkiego, tłum. D. Misztal, T. Sieczkowski, Kraków 2004, s. 9.

${ }^{61}$ Tamże, s. $12 \mathrm{n}$.

${ }^{62}$ Zob. T. Sieczkowski, Postowie: Geografia umystu wedtug Davida Hume'a, [w:] D. Hume, Badania dotyczace rozumu..., dz. cyt., s. 161 n.

${ }^{63}$ D. Hume, Traktat o naturze ludzkiej, thum. C. Znamierowski, t. 1, Warszawa 1963, s. 127; tenże, Badania dotyczace rozumu..., dz. cyt., s. 42.

${ }^{64}$ Tamże, s. 17.

${ }^{65}$ Tamże.

${ }^{66}$ Hume odrzuca możliwość ontologicznego istnienia związku przyczynowo-skutkowego. Powiązanie między przyczyną i skutkiem ma charakter wyłącznie umysłowy. Jest to jedna z zasad asocjacji, która zachodzi w psychice podmiotu poznającego.

${ }^{67}$ D. Hume, Badania dotyczace rozumu..., dz. cyt., s. 26, 28, 30.

${ }^{68}$ Tamże, s. 27.

${ }^{69}$ Tamże, s. 33.

${ }^{70}$ Tamże, s. 37. 
się do procesów intelektualnych. Jest nią przyzwyczajenie, utożsamiane przez Hume'a z nawykiem ${ }^{71}$.

Zasadą tą jest nawyk, czyli przyzwyczajenie [custom or habit]. [...] musimy zatem przyznać, że jest to ostateczna możliwa do wskazania podstawa wszystkich naszych wniosków wypływających $\mathrm{z}$ doświadczenia ${ }^{72}$.

Hume idzie dalej i orzeka coś więcej ponad to, że przyzwyczajenie jest podstawą wniosków wyprowadzanych z doświadczenia. Przyzwyczajenie stanowi ,wielki przewodnik ludzkiego życia” i bez niego nie mielibyśmy ,żadnej wiedzy dotyczącej faktów"73 poza odbieranymi bezpośrednio impresjami.

Odwołanie do przyzwyczajenia w kwestii kojarzenia idei (asocjacji) jest rzeczą popularną w nowożytnej filozofii. W tej kwestii myśl Hume’a wyprzedza John Locke $^{74}$, po Humie zaś podobną myśl formułuje Immanuel Kant ${ }^{75}$, tyle że Locke i Kant, w odróżnieniu od Hume'a, wypowiadają się w kwestii przyzwyczajenia raczej negatywnie. Sam Hume, uciekając się do wpisania przyzwyczajenia w stałe wyposażenie natury ludzkiej, nie określa bliżej jego charakteru, stwierdza jedynie, że nie sposób wskazać na przyczyny tej przyczyny ${ }^{76}$.

Dla Hume'a wiedza jest wsparta na przyzwyczajeniu/nawyku. Przyzwyczajenie zaś wiąże się z przeświadczeniem (belief), dlatego że umysł - kierowany przyzwyczajeniem i uporządkowany dzięki zasadom asocjacji idei - oczekując pojawienia się danej regularności, wytwarza w sobie przeświadczenie o jej występowaniu ${ }^{77}$. Hume stwierdza, że przeświadczenie jest koniecznym rezultatem znajdowania się w okolicznościach występowania danej regularności. Przeświadczenie jest dla Hume’a ważną kategorią, gdyż stanowi zasadę wiedzy ${ }^{78}$. Jednakże, ze względu na zawarty w przeświadczeniu element wątpienia, nie można budować nań wiedzy pewnej, a jedynie prawdopodobną ${ }^{79}$.

${ }^{71}$ Hume zamiennie używa słowa custom (D. Hume, An enquiry concerning human understanding, Indianapolis 1993, s. 18, 28, 29, 30, 31, 35, 36, 38, 55, 57, 71, 110) ze słowem habit (tamże, s. 7, 46, 50). Zdarza się, że Hume posługuje się zwrotem the force of custom (tamże, s. 31), co można thumaczyć jako: „siła przyzwyczajenia” lub „siła zwyczaju”. Kontekst, umiejscawiający custom w wyobraźni podmiotowej, podpowiada, że thumaczenie tego słowa przez „zwyczaj” byłoby niefortunne. Można zatem przyjąć, że dla Hume’a przyzwyczajenie niczym nie odróżnia się od nawyku.

${ }^{72}$ D. Hume, Badania dotyczace rozumu ..., dz. cyt., s. 38.

${ }^{73}$ Tamże, s. 39.

${ }^{74}$ J. Locke, Rozważania dotyczace rozumu ludzkiego, tłum. W. M. Kozłowski, Warszawa 2011, s. $464,471$.

${ }^{75}$ I. Kant, Antropologia w ujęciu pragmatycznym, dz. cyt., s. 81.

${ }^{76}$ Por. D. Hume, Badania dotyczace rozumu ..., dz. cyt., s. 38.

77 Tamże, s. 41.

${ }^{78}$ Zob. T. Sieczkowski, Postowie: Geografia umystu..., dz. cyt., s. 171.

${ }^{79}$ D. Hume, Traktat o naturze..., dz. cyt., s. 238. 
Przyzwyczajenie można silnie powiązać z tematyką przekonań. Filozofowie od okresu antycznego prowadzą spory o to, czy wszystkie przekonania tworzą wiedzę. Problem przekonań ma swe źródło w filozofii greckiej, a dokładnie w zagadnieniu odróżnienia episteme, tj. wiedzy, od doxa, tj. przekonania, mniemania ${ }^{80}$. Problem związany jest z tym, iż często przyjmuje się, że wszystkie przekonania stanowią warunek uzyskania wiedzy. Jednakże przekonania, choć mogą być przydatne w dążeniu do prawdy, nie zawsze stanowią wiedzę ${ }^{81}$.

Jan Sochoń, analizując stanowisko Parmenidesa ${ }^{82}$ w sprawach epistemologicznych, zauważa, że za przekonaniami kryją się czasem zwyczajne poglądy, które charakteryzują się tylko znamionami prawdopodobieństwa, nie mają zaś związku z prawdą. We współczesnej epistemologii pośród wielu teorii wiedzy można znaleźć taką, która stwierdza, że wiedza jest prawdziwym i uzasadnionym przekonaniem. Jest to tzw. „klasyczna koncepcja wiedzy”. Taka definicja wiedzy, jak wskazuje Woleński, była rozważana już przez Platona, lecz popularność zyskała dopiero w XX wieku ${ }^{83}$. Takie rozumienie wiedzy związane jest $\mathrm{z}$ tezą, że nie każde uznawane przekonanie jest w pełni uzasadnione. Podmiot bowiem może nie być świadom tego, że istnieją dowody potwierdzające prawdziwość sądów przeciwnych jego przekonaniom.

Problematykę tę można odnieść do Hume'a. Jego zdaniem na podstawie prawdopodobieństwa związanego $\mathrm{z}$ występowaniem danego zjawiska powstaje przekonanie o wystąpieniu skutku, który zwykle powstawał w jego efekcie. Dzięki przyzwyczajeniu do tej regularności można żywić przekonanie, że tak się dzieje zawsze w określonych warunkach. Jednakże posiadanie przekonania o prawdopodobieństwie nie przesądza o jego prawdziwości, gdyż prawdopodobieństwo nie jest nigdy równe pewności. Przyzwyczajenie może się okazać zawodne, gdyż podmiot może nie posiadać wystarczających przesłanek dla uzasadnienia danego biegu rzeczy. Zgodnie z klasyczną koncepcją wiedzy „,wiedza” z przyzwyczajenia, z racji prawdopodobieństwa i subiektywności, bliższa jest mniemaniom niż wiedzy w sensie ścisłym. Warto w tym miejscu przypomnieć stwierdzenie Montaigne’a, który mówi, że przyzwyczajenie nie napotyka oporu w duszy - „Czegóż nie może ono uczynić z naszym sądem i wierzeniami!" ${ }^{4}$.

${ }^{80}$ Zob. J. Sochoń, Przekonania - Bóg - moralność (Wybrane głosy z historii filozofii), „Człowiek w Kulturze" 1995 nr 4-5, s. 123; J. Woleński, Epistemologia, dz. cyt., s. 18n, 370-373.

${ }^{81}$ Zob. J. Sochoń, Przekonania..., dz. cyt., s. 123 n.

${ }^{82}$ Warto dodać, że Parmenides miał do przyzwyczajenia stosunek negatywny z racji jego wpływu na kształtowanie mniemań. Może o tym świadczyć następujący cytat: „Oby siła przyzwyczajenia nie zmusiła cię kroczyć po tej drodze, / na której wyrokuje nieodpowiedzialne oko, słuch chwytający odgłosy, a także język; / tylko rozumem rozsądzaj najbardziej sporny i najważniejszy problem" (Parmenides - cyt. za: D. Laertios, Żywoty i poglady słynnych filozofów, tłum. I. Krońska, Warszawa 1982, s. 528).

${ }^{83}$ J. Woleński, Epistemologia, dz. cyt., s. 367.

${ }^{84}$ M. de Montaigne, Próby, thum. T. Boy-Żeleński, t. 1, Warszawa 2009, s. 212. 
Na splot przyzwyczajenia i mniemania zwraca uwagę Brentano. Stwierdza on bowiem, że nie każdy sąd uznawany za prawdziwy jest taki w rzeczywistości. Zdarza się, że ludzie wydają sądy „na ślepo”, bez słusznego uzasadnienia, kierowani ,instynktowną skłonnością" ".5. Dlatego też Brentano dzieli sądy na ,jasne” („oczywiste”) i ,ślepe” (,przesądy”). Sądy ,jasne” należą do wyższego sposobu sądzenia, natomiast „ślepe” - do niższego. Sądy „ślepe” wynikają z podążania za przyzwyczajeniem, choć przeczą niekiedy logicznemu uzasadnieniu. Brentano odróżnia oczekiwania oparte na przyzwyczajeniu od oczekiwań rozumnych, opartych na wyliczeniu prawdopodobieństwa ${ }^{86}$. Wprawdzie krytycznie odnosi się on do sądów ślepych, lecz podkreśla przy tym, że nawet te sądy mają znaczący udział w poznaniu. Brentano wskazuje również na to, że sądy oparte na przyzwyczajeniu mogą być niekiedy trafne lub zgodne z prawdopodobieństwem.

Tak to ślepe, oparte jedynie na przyzwyczajeniu oczekiwanie podobnego w podobnych przypadkach [...] zgadza się nierzadko z wynikami, których w tej samej sytuacji dostarczyłaby indukcja przeprowadzona zgodnie z prawami rachunku prawdopodobieństwa ${ }^{87}$.

Brentano nie ogranicza się do wskazania związku mniemań z prawdopodobieństwem. Twierdzi, że mniemania mogą być prawdziwe, choć dostrzega, że dzieje się to jednak raczej z przypadku ${ }^{88}$. Jego zdaniem przyzwyczajenie wpływa na powstawanie mniemań niezgodnych z przesłankami rozumowymi, choć można wskazać na - powstały raczej na zasadzie przypadku - związek przyzwyczajenia z prawdą.

Można przyjąć, że przyzwyczajenie stanowi kategorię epistemologiczną ze względu na wpływ na kształtowanie wiedzy, udział we władzach poznawczych, a także zbieżność z tematyką przekonań. W kwestii przekonań można wskazać na problematyczność ujmowania przyzwyczajenia w odniesieniu do prawdziwości, choć można dostrzec, że różni filozofowie nie wykluczają wiązania tych kategorii. Zwraca się uwagę na związek przyzwyczajenia z przesądami i mniemaniami, dlatego że wydaje się ono bliższe przekonaniom bazującym na prawdopodobieństwie i subiektywności.

\section{Przyzwyczajenie jako kategoria estetyczna}

Estetyka boryka się z problemami natury metodologicznej. Estetycy do dziś spierają się o właściwy przedmiot tej dyscypliny - jedni skupiają się na samym

\footnotetext{
${ }^{85}$ F. Brentano, O źródle..., dz. cyt., s. 22n.

${ }^{86}$ Tamże, s. $91 \mathrm{n}$.

${ }^{87}$ Tamże, s. 44n.

${ }^{88}$ Tamże, s. 22n.
} 
pięknie, inni wolą przesunąć akcent na piękno sztuki lub po prostu na sztukę piękną, a jeszcze inni odwołują się do pojęcia doświadczenia estetycznego ${ }^{89}$. Problematyczne okazuje się również samo rozumienie początku tej dyscypliny. Według Günthera Pöltnera estetykę można rozumieć w znaczeniu szerokim, włączającym cały dziejowy kontekst myśli estetycznej, oraz wąskim, ograniczającym badania estetyki do refleksji rozpoczętej przez Alexandra Gottlieba Baumgartena, mającej początek w epoce nowożytnej ${ }^{90}$. Dla niniejszych rozważań przyjmowane jest znaczenie szerokie, podążające za estetyczną myślą nad pięknem, sztuką i fenomenami im pokrewnymi w całym kontekście dziejowym. W związku z tym rozważania nad przyzwyczajeniem dotyczyć będą zarówno ujęcia piękna, jak i sztuki.

Pierwszym kluczowym pojęciem z zakresu estetyki jest piękno. Władysław Tatarkiewicz za najdłużej obecną w dyskursie estetycznym teorię opisującą piękno uznaje wywodzącą się z uogólnienia pitagorejskich wyników tzw. Wielką Teorię ${ }^{91}$. U jej podstaw leży postrzeganie piękna przez pryzmat doboru proporcji części we właściwy układ, co związane jest z tendencją do osiągnięcia pewnej harmonii. Wielka Teoria, powstała na fundamencie filozofii pitagorejskiej, wypływa z rozumienia świata jako harmonijnego i uporządkowanego, rządzonego prawami konieczności.

Claude Perrault dokonuje krytyki Wielkiej Teorii, zauważając wyłom w postrzeganiu piękna przez pryzmat doboru proporcji części w układzie. Uznaje on, że nie ma proporcji lepszych ani gorszych, one tylko wydają się takimi z powodu przyzwyczajenia, skojarzenia i konwencji ${ }^{92}$. Stwierdza również, że proporcje, które były uważane za bezwzględnie piękne, podobają się ludziom nie dlatego, że w istocie takie są, lecz dlatego że ludzie do nich przywykli. Innymi słowy, twierdzi, że dane proporcje kojarzą się z pięknymi obiektami, a reszty dokonuje przyzwyczajenie. O uprzywilejowaniu danych proporcji nie decyduje więc ani natura, ani konieczność, lecz przypadek. U Perraulta piękno jest kwestią psychiki i powszechnej zgody co do upodobań oraz przyzwyczajenia do nich. Tak ujęte piękno zostaje znacząco zrelatywizowne i zsubiektywizowane. Dla Perraulta piękno jest uzależnione od przyzwyczajenia i dlatego nic w naturze nie jest piękne samo przez się.

Jego poglądy wywołały jednak sprzeciw François Blondela, który twierdzi, że tezy Perraulta są błędne, gdyż przyzwyczajenia są zmienne i można wskazać na rzeczy, które niezmiennie się ludziom podobają ${ }^{93}$. Blondel uznaje istnienie obiektywnego piękna, które lokalizuje w naturze samej rzeczy - jest ono uzależnione od układu części i właściwych proporcji, a wywołuje upodobanie w ludziach ze względu na powszechną zgodność co do tego, co jest piękne obiektywnie. Samo postrzeganie

\footnotetext{
${ }^{89}$ Zob. G. Pöltner, Estetyka filozoficzna, tłum. J. Zychowicz, Kraków 2011, s. 11-18.

${ }^{90}$ Tamże, s. 15-16.

${ }^{91}$ W. Tatarkiewicz, Dzieje sześciu pojęć, Warszawa 1988, s. 140-156.

${ }^{92}$ Zob. tamże, s. 156, 248, 250.

${ }^{93}$ Zob. tamże, s. 248 n.
} 
piękna wywodzi on z natury, dlatego że sztuka - zarówno architektoniczna, malarska, jak i rzeźbiarska - odwzorowuje formy i proporcje zawarte w naturze. Nie jest zatem możliwe wyprowadzenie upodobań z przyzwyczajeń, gdyż przedmioty piękne są piękne same w sobie i nie ma potrzeby się do nich przyzwyczajać.

Z kolei Edmund Burke ukazuje, skąd się biorą przesądy przypisujące Wielkiej Teorii tak ogromną wartość. Jego zdaniem ludzie uważają odpowiedni układ proporcji za przyczynę piękna, gdyż nie obserwują zniekształceń w postrzeganym przedmiocie. Jednakże zniekształcenia stanowią przeciwieństwo normalnej postaci, nie zaś piękna. Natomiast ludzie przywykają do normalnej postaci dzięki uprzednim doświadczeniom. Z kolei to, co przyzwyczaili się uznawać za normalną postać, nie musi być piękne ${ }^{94}$. Poglądy Perraulta, Blondela i Burke’a wpisują się w tzw. spór obiektywizmu z subiektywizmem ${ }^{95}$. Zarówno Wielka Teoria, jak i ten spór rozwijają się równolegle z osadzonymi historycznie filozoficznymi tendencjami i stanowią próby odwzorowania świata zgodnie z duchem czasu.

Tatarkiewicz ukazuje, jak od piękna postrzeganego jako właściwość przyrodzonego świata myśl estetyczna ewoluuje do dwudziestowiecznej tendencji ${ }^{96}$ hołdującej idei, że ,piękno jest wyłącznie w sztuce"97. Problem sztuki, podobnie jak piękna, jest związany z postrzeganiem świata. Tyle że ujęcie piękna wynika ze sposobu jego rozumienia, sztuka zaś próbuje owo rozumienie naśladować. Idea teorii naśladownictwa (mimesis), u Tatarkiewicza figurująca pod nazwą Dawnej Teorii ${ }^{98}$, ma swój rodowód w starożytnej Grecji. Pomijając specyfikę wynikającą z ustaleń systematycznych poczynionych przez różnych filozofów i problematyczność interpretacji kluczowych pojęć, można przyjąć, że mimesis jest naśladowaniem lub odtwarzaniem rzeczywistości, tj. przyrody lub też natury, oraz jej praw ${ }^{99}$.

Ujęcie sztuki jako naśladującej prawa natury leży u podstaw współczesnego systemu estetycznego Umberta Eco. W swoim zbiorze esejów Sztuka stwierdza on, że źródło idei przyzwyczajenia, które stanowi dla niego czynnik skostnienia, ma swoje silne ugruntowanie historyczne $\mathrm{i}$ teoretyczne oraz że jest to istotnie skorelowane z postrzeganiem natury jako niezmiennej. Według niego świat jest przykładem przyzwyczajenia ${ }^{100}$.

${ }^{94}$ Zob. G. Pöltner, Estetyka ..., dz. cyt., s. 70-73.

${ }^{95}$ Spór ten opisany został przez W. Tatarkiewicza - por. tenże, Dzieje ..., dz. cyt., s. 228-256.

${ }^{96}$ Co prawda rola sztuki w dziejach estetyki wychodzi na światło dzienne dużo wcześniej. Tatarkiewicz zauważa, że zbliżenie pojęcia piękna z pojęciem sztuki można datować na okres Odrodzenia i jest to niewątpliwie zdarzenie przełomowe w estetyce. Niemniej przekierowanie uwagi z piękna na sztukę następuje o wiele później, a najwięcej radykalności przynoszą najnowsze tendencje - zob. tamże, s. 169.

${ }_{97}$ Tamże, s. 175.

${ }^{98}$ Tamże, s. 323.

${ }^{99}$ Zob. tamże, s. 313, 323, 342n.

${ }^{100}$ U. Eco, Postępowa funkcja nowoczesnego malarstwa, tłum. M. Salwa, [w:] tenże, Sztuka, Kraków 2008, s. 230. 
Pomysł powiązania ogólnej idei świata z ideą przyzwyczajenia Eco czerpie od Arystotelesa, dla którego przyzwyczajenie stanowi ludzkie odzwierciedlenie dążenia rzeczy w świecie do stanu naturalnego. Innymi słowy, w świecie ludzkim można znaleźć odpowiednik koniecznych praw rządzących niezmienną przyrodą. W przyrodzie zawarte jest pojęcie „,zawsze”, w świecie ludzkim jego odpowiednikiem jest pojęcie „często”. Idea przyzwyczajenia, w które wpisane jest „często”, opiera się na przekonaniu, że człowiek naśladuje niezmienność zawartą w świecie. Eco stwierdza, że tradycyjne przekonanie o niezmienności natury pociąga sztukę do próby naśladowania świata takiego, jaki jest, w „,Zwyczajny sposób”, zgodnie z przyzwyczajeniem - poprzez nie bowiem człowiek naśladuje świat i niezmienną naturę. Dlatego też „przyzwyczajenie jest pewnym optimum"101.

Eco twierdzi, że sztuka podejmuje próbę odzwierciedlenia rzeczywistości dostępnej dzięki naukowemu opisowi. Zwraca uwagę na to, że średniowieczne dzieła odzwierciedlają ideę porządku i logikę konieczności. W nowożytności pojawiła się tendencja do odkrywania nowego porządku ${ }^{102}$. Prawdziwy przełom dokonuje się jdenak w czasach współczesnych, kiedy to cała wcześniejsza wizja świata opisywana przez naukę zostaje wywrócona „do góry nogami”. W kulturze współczesnej rozpoczyna się kryzys pojęcia „Uporządkowanego Kosmosu” ${ }^{103}$. Sztuka współczesna, przejmując od nauki wizję świata, zaczyna łamać schematy dostarczane przez klasyczną estetykę, współgrającą z odmiennym obrazem świata - przewidywalnego i uporządkowanego. Jeśli nawet porządek panujący w świecie budzi w jakimś stopniu opór w artystach reprezentujących sztukę klasyczną, to we współczesnej sztuce przybiera postać skrajną, bo nie jest już tylko przejawem oporu, lecz pewną stałą tendencją do wykraczania poza wszelkie dotychczas przyjęte schematy.

Sztuka zatem, stwarzając swój specyficzny rodzaj porządku, dąży do wykraczania poza prawdopodobne rozwiązania i tworzenia „ładu w najwyższym stopniu «nieprawdopodobnego»" ${ }^{104}$. Jest to więc raczej nieład „nieliczący się z podmiotem przywykłym do poruszania się wśród rozkładów probabilistycznych" ${ }^{105}$. Człowiek tradycyjny jest przyzwyczajony do danego widzenia świata i dzięki niemu naśladuje naturę w sztuce. Podczas gdy obraz świata ulega zmianie, skostniałe przyzwyczajenie podąża nadal za utartymi schematami estetycznymi. We współczesną sztukę wpisane jest natomiast dążenie do łamania schematów ustalonych przez przyzwyczajenie.

\footnotetext{
${ }^{101}$ Tamże.

${ }^{102}$ Tenże, Poetyka dzieła otwartego, thum. J. Gałuszka, [w:] tenże, Dzieło otwarte. Forma i nieokreśloność w poetykach współczesnych, Warszawa 2008, s. 86n.

${ }^{103}$ Tenże, Wstęp do wydania pierwszego, thum. K. Żaboklicki, [w:] tenże, Dzieło otwarte..., dz. cyt., Warszawa 2008, s. 33.

${ }^{104}$ Tenże, Otwarcie, informacja, komunikacja, tłum. J. Gałuszka, [w:] tenże, Dzieło otwarte..., dz. cyt., s. 191.

${ }^{105}$ Tamże, s. 157; por. A. Berleant, Prze-myśleć estetykę. Niepokorne eseje o estetyce i sztuce, tłum. M. Korusiewicz, T. Markiewka, Kraków 2007, s. 65, 75.
} 
Sztuka wyrzeka się przy tym schematów, które wskutek przyzwyczajeń psychologicznych i kulturowych zakorzeniły się tak głęboko, że wydawały się wręcz „naturalne”106.

Sztuka zmuszona jest do szukania nowych form, często poddając próbie oczekiwania widza wobec spodziewanych rozwiązań, działając na przekór jego przyzwyczajeniu $^{107}$. Ponieważ oczekiwania widza mogą nie współgrać z nowymi propozycjami artystów, które znacząco wykraczają poza przyzwyczajenia odbiorców, Eco znajduje receptę na kryzys wywołany pojawieniem się nowych form sztuki. Jest nią ,przyzwyczajenie do nieprzyzwyczajania się”.

Człowiek en bloc musi przyzwyczaić się do tego, by już do niczego nigdy się nie przyzwyczajać, musi uznać zmienność, rewizję schematów, dynamikę ciągle nowych sposobów bycia w świecie i postrzegania świata za naszą normalną i uprzywilejowaną kondycję ${ }^{108}$.

Zdaniem Eco człowiek musi wyciągnąć wnioski z tej lekcji sztuki współczesnej i - zamiast pogrążać się w stagnacji, skostnieniu i schematyzowaniu - uznać zmienność, rewizję schematów oraz dynamiczność związaną z „nową kondycją” człowieka i jego nowymi „sposobami bycia w świecie”. Do tego potrzebuje idei przyzwyczajania się do nieprzyzwyczajania się.

Człowiek, łamiąc powszechnie obowiązujące schematy, do których był przyzwyczajony, jest istotą wolną - może wybierać spośród bogatego spektrum różnorodnych form. Jego świat, tak jak świat naukowców, nie jest już jednorodny i monistyczny, lecz staje się ,policentrycznym uniwersum”. Tak więc człowiek współczesny zrywa „z kulturowymi przyzwyczajeniami oraz traci poczucie centrum wszechświata, w którym się znajduje, przyzwyczajając się do uniwersum policentrycznego" ${ }^{109}$. Owe uniwersum pełne jest różnorodnych dróg, którymi artysta może kroczyć, przecierając nowe szlaki. Eco przytacza myśl znanego kompozytora i muzykologa, Bogusława Schäffera, który stwierdza, że muzyk powinien porzucać stare doświadczenia, wynajdywać nowe ścieżki formalne i przyzwyczajać się do takich relacji dźwiękowych, do których nikt nie chciałby się przyzwyczajać ${ }^{110}$. Istnieje jednak pewne ryzyko, że poszukiwanie nowych form przerodzi się w regułę dążenia zawsze do uzyskania czegoś nowego, a więc w ,przyzwyczajenie do eksperymentu"111. Poza tym odbiorca dzieła może z czasem przyzwyczaić się do

\footnotetext{
${ }^{106}$ U. Eco, Wstęp do wydania..., dz. cyt., s. 34.

${ }^{107}$ Tenże, Konieczność i możliwość w strukturach muzycznych, thum. M. Salwa, [w:] tenże, Sztuka, dz. cyt., s. 185 .

${ }^{108}$ Tenże, Postępowa funkcja..., dz. cyt., s. 232.

${ }^{109}$ Tenże, Konieczność i możliwość..., dz. cyt., s. 190.

${ }^{110}$ Tenże, Eksperymentalizm i awangarda, tłum. P. Salwa, [w:] tenże, Sztuka, dz. cyt., s. 245.

111 Tamże, s. 252.
} 
nowych rozwiązań i dzieło może się zużyć lub być postrzegane jako pospolite ${ }^{112}$. Zużycie się form wiąże z „przyzwyczajenia do bodźca”, które wynika z osłabienia uwagi skierowanej na działający bodziec, którym jest określona forma ${ }^{113}$. Dlatego Eco zwraca uwagę na to, że odbiorca dzieła zmuszony jest postrzegać je w nowy sposób, nabrać przyzwyczajenia „,patrzenia na rzeczy w sposób niecodzienny”"114.

Wszystkie te rozważania związane są ze sformułowanym przez estetyka projektem „dzieła otwartego" ${ }^{115}$, w który wpisana jest idea otwartości jako konieczny element dzieła, wymuszony przez ewolucję nauki i odkrycie takich zjawisk, jak wielowartościowość. Najważniejszą cechą dzieła otwartego jest przede wszystkim to, że o jego ostatecznej formie decyduje interpretator ${ }^{116}$. Ten charakter dzieła, które nie jest dziełem skończonym, lecz podlega ciągle nowej interpretacji, może posłużyć do określenia nowej dialektyki między dziełem i interpretatorem. Dla Eco współczesna sztuka to rodzaj dialektyki między „,nowymi formami i przyzwyczajeniem odbiorców do nich" ${ }^{117}$. Z jednej strony, odbiorca konfrontuje formę dzieła, łączącą często elementy nieokreśloności i nieprzewidywalności, ze swoim przyzwyczajeniem, $\mathrm{z}$ drugiej strony natomiast, twórca dzieła zmuszony jest do poszukiwania nowych rozwiązań, pomagających przezwyciężyć przyzwyczajenia odbiorcy. Dlatego też przyzwyczajenie odgrywa istotną rolę w systemie estetycznym Eco.

Podsumowując: przyzwyczajenie w estetyce pojawia się niejednokrotnie w obrębie różnych dyskursów i ukazywane jest z różnych stron, wieloaspektowo. W związku z ważnością zjawiska przyzwyczajenia, ujawniającą się w bogactwie rozważań estetycznych, tj. w podkreślaniu roli przyzwyczajenia w ujmowaniu zarówno piękna, jak i sztuki, a także w konstruowaniu i recepcji dzieł estetycznych, przyzwyczajenie można uznać za kategorię estetyczną. Nie bez powodu Tatarkiewicz stwierdził, że „przyzwyczajenie jest decydującym momentem w sądzie o sztuce”"118.

\section{Znaczenie przyzwyczajenia}

W tej części zostaną zebrane powyższe wątki dla ukazania roli przyzwyczajenia w kształtowaniu nie tylko pojedynczych aspektów ludzkiego życia, ale i całej

\footnotetext{
${ }^{112}$ Tenże, Otwarcie, informacja..., dz. cyt., s. 141.

${ }^{113}$ Tenże, Analiza języka poetyckiego, thum. J. Gałuszka, [w:] tenże, Dzieło otwarte..., dz. cyt., s. 121.

${ }^{114}$ Tenże, Przypadek i intryga. Doświadczenie telewizji a estetyka, tłum. A. Kreisberg, [w:] tenże, Dzieło otwarte..., dz. cyt., s. 241.

${ }^{115}$ Szczegółowe opracowanie istoty „dzieła otwartego” są przedstawione w: tenże, Problem dzieła otwartego, tłum. P. Salwa, [w:] tenże, Sztuka, dz. cyt., s. 164-174.

${ }^{116}$ Tenże, Poetyka dzieła ..., dz. cyt., s. 69.

${ }^{117}$ Tenże, Eksperymentalizm i awangarda, thum. P. Salwa, [w:] tenże, Sztuka, dz. cyt., s. 254, 261.

${ }^{118}$ W. Tatarkiewicz, Przedmowa do wydania pierwszego, [w:] J. Żórawski, O budowie formy architektonicznej, Warszawa 1973, s. 11.
} 
kondycji człowieka zgodnie z myślą, że filozofia stanowi dążenie „do zdobycia ostatecznej wiedzy o całości" ${ }^{119}$. Natomiast najpełniej filozoficzne dążenie do zyskania wiedzy systematycznej o człowieku uwidacznia się w antropologii, która formułuje ,powszechnie obowiązujące twierdzenia, czym on [człowiek] jest jako taki"120. Jak twierdzi Gerd Haeffner, człowiek, pytając o swoją istotę - odnosi to pytanie na istotę wszystkich ludzi, a przez to, że buduje teorię, która odnosi się do każdego, odnosi ją na powrót na siebie ${ }^{121}$. Wydaje się, że pytanie o przyzwyczajenie dotyka zagadnienia kondycji ludzkiej, przyzwyczajenie może więc stanowić kategorię antropologiczną. Syntetyczne zebranie wątków dotąd poruszanych nie oznacza jednak, że z rozważań etycznych, epistemologicznych czy estetycznych można wyprowadzić wnioski antropologiczne. Antropologię należy traktować jako odrębną subdyscyplinę filozoficzną, mimo iż właściwa jej problematyka może się znacząco pokrywać z zagadnieniami rozważanymi w innych dziedzinach nauki.

Biorąc pod uwagę wcześniejsze analizy, można powiedzieć, że pojęcie przyzwyczajenia opisuje sposób funkcjonowania i nabywania zachowań moralnych (etyka), zdolności poznawczych (epistemologia) i sposobu ujmowania zjawisk estetycznych (estetyka). Wskazywano również na to, że przyzwyczajenie może być opisywane wielostronnie, można bowiem wyróżnić następujące jego aspekty.

W sferze moralności przyzwyczajenie występuje jako nawyk lub sprawność. Tak pojmowane przyzwyczajenie może być rozpatrywane jako wspomagające lub utrudniające funkcjonowanie życia moralnego. Może ono opisywać również skłonność, tendencję czy dyspozycję do określonych zachowań. W tych sensach bywa pojmowane jako ,prymitywna tresura”, „quasi-inteligentny mechanizm podtrzymujący życie”, „konieczność subiektywno-praktyczna”. Przyzwyczajenie może być również rozumiane jako sam proces zmierzający do ukształtowania nawyku lub sprawności.

Przyzwyczajenie rozpatrywane w kategoriach mniemań czy przesądów, m.in. opisywane jako determinant subiektywnych przekonań, może także stanowić część świata umysłowego. W zależności od założonej koncepcji jest odnoszone do tworzenia wiedzy na podstawie doświadczenia lub rozumiane jako siła uwarunkowująca ocenianie, albo też przyrównywane do bliżej nieokreślonego stanu psychicznego. Może być również rozumiane jako tendencja do zmysłowego pomijania wrażeń długotrwale działających na organizm. Jest pojmowane z jednej strony jako „tajemna siła”, „przewodnik ludzkiego życia”, „zasada, która czyni doświadczenie użytecznym”, z drugiej zaś jako ,instynktowna skłonność” warunkująca „ślepe sądy”. Te ujęcia przyzwyczajenia najlepiej uwidaczniają się w sferze poznania.

\footnotetext{
${ }^{119}$ G. Haeffner, Wprowadzenie do antropologii filozoficznej, thum. W. Szymona, Kraków 2006, s. 15.

${ }^{120}$ Tamże.

${ }^{121}$ Tamże, s. 19.
} 
Przyzwyczajenie może również uwarunkowywać upodobania do określonych przedmiotów, wpływać na ich postrzeganie. Uczestniczy w tworzeniu i rozumieniu, co widoczne jest w aktywności twórczej artystów i recepcji odbiorców dzieł artystycznych. Niekiedy pojmuje się je jako „czynnik skostnienia”, czasem jako pewne optimum. Jest rozumiane jako ludzki odpowiednik natury, w którym jest zawarte pojęcie „,często”, odzwierciedlające tkwiące w przyrodzie słowo „zawsze”. Te sensy przyzwyczajenia są ściśle związane z szeroko pojętą sferą estetyczną.

Widać wyraźnie, że przyzwyczajenie mimo wielostronności ujęć jest ściśle związane $\mathrm{z}$ aktywnością podmiotową $\mathrm{w}$ obrębie różnych sfer. Ponadto zaprezentowane ujęcia wpisują przyzwyczajenie w dyskurs o podstawowych wartościach, takich jak dobro, prawda i piękno.

W kwestii dobra przyzwyczajenie jest ujmowane w kontekście podmiotowych uwarunkowań związanych z moralnością. Jest ono rozumiane jako dyspozycja do działań posiadających lub nieposiadających wartości moralnej, a w przypadku systemu Arystotelesa jest rozpatrywane jako mające wpływ na kształtowanie cnoty ukierunkowanej na osiągnięcie dobra jako najwyższej wartości moralnej.

W kwestii prawdy przyzwyczajenie często utożsamiane jest z przesądami czy mniemaniami, gdzie w wątpliwość podana zostaje ich prawdziwość z racji zakładanego prawdopodobieństwa lub subiektywistycznych uwarunkowań. Bywa również uznawane za podstawę wiedzy.

W kwestii piękna przyzwyczajenie wiązane jest najczęściej z subiektywnym postrzeganiem wartości estetycznej lub też z konstruowaniem i recepcją dzieł estetycznych jako posiadających wartość estetyczną. Niektórzy filozofowie wprost uzależniają ujmowanie lub ocenę piękna od przyzwyczajenia.

Można zatem stwierdzić, że poza typowym wpływem przyzwyczajenia na aktywność podmiotową uwidacznia się jego związek z postrzeganiem uniwersum wartości. Najczęściej zależność ta wiązana jest z relatywizacją i subiektywizacją wartości, choć należy podkreślić, że charakterystyka przyzwyczajenia uzależniona jest od przyjmowanych założeń systemowych, a w związku z tym może podlegać odmiennej ewaluacji.

Rozpatrując przyzwyczajenie od strony jego etiologii, można ujmować je dwojako. Interpretując je jako swego rodzaju zdolność, jako „tajemny” mechanizm wpisany w biologiczną naturę człowieka, można wskazać na jego wrodzoność. Interpretując je jako wyuczoną formę zachowania, należy je rozpatrywać jako coś nabytego. Przyzwyczajenie jako pojęcie niejednorodne uwikłane jest zatem w dyskurs filozoficzny na temat dychotomii wrodzone-nabyte. Z jednej strony, przyzwyczajenie może być odnoszone do naturalnego wyposażenia człowieka, czyli rozpatrywane jako naturalny czynnik działający zarówno na sferę zmysłów, jak i rozumu. $Z$ drugiej zaś strony można wskazać na inną możliwość jego odniesienia - w kontekście świadomego lub nieświadomego kształtowania (uczenia się) pewnych zachowań lub nabywania pewnych informacji o świecie. Manifestują 
się tu dwa odmienne aspekty tego pojęcia, które mogą być rozpatrywane w sensie filogenetycznym oraz ontogenetycznym. Każdy bowiem rodzi się ze zdolnością do przyzwyczajania się, ale też może nabywać nowych przyzwyczajeń w ciągu całego życia. W pojęciu tym łączą się zatem dwie intuicje, które filozofowie klasyczni konsekwentnie starali się od siebie oddzielać. Wydaje się, że w tym kontekście przysłowiowe określenie przyzwyczajenia jako „drugiej natury” staje się pełniejsze, bowiem z jednej strony zdolność przyzwyczajania się jawi się jako naturalna, gdyż jest stałym, biologicznym wyposażeniem człowieka, z drugiej zaś to, do czego człowiek się przyzwyczaja, staje się dla niego tak naturalne, że zaczyna to widzieć jako coś dla siebie specyficznego.

Zagadnienie przyzwyczajenia dotyka wielu ważnych wymiarów kondycji człowieka i w związku z tym można je potraktować również jako kategorię antropologiczną.

\section{$*$}

W ramach podsumowania można się odnieść do cech kategorii przytoczonych na wstępie artykułu. Wydaje się, że przyzwyczajeniu można przypisać wszystkie cechy kategorii.

Przyzwyczajenie odnosi się do szerokiego spektrum problemów i zagadnień rozpatrywanych w historii myśli i stanowi etykietę dla ich uogólnień - jest to szczególnie widoczne w zestawieniu z fundamentalnymi dychotomiami filozoficznymi.

Przyzwyczajenie jest kategorią występującą powszechnie, lecz nie można jej określić mianem koniecznej ani niezmiennej - jest ono w dużej mierze uwarunkowane podmiotowo i występując w różnych postaciach, dotyka wielu sfer ludzkiej aktywności, w związku z tym nie może być uznane za niezmienne ani tym bardziej konieczne.

Z racji dużego zasięgu kategoria przyzwyczajenia wyznacza i ukierunkowuje pewne pole teoretyczne - dlatego może dotyczyć zagadnień klasycznie umiejscawianych w obrębie poszczególnych subdyscyplin i podlegać wielostronnej analizie.

Przyzwyczajenie ukierunkowujące pewne pole teoretyczne samo stanowi jego centrum, a w związku z tym rzutuje na przebieg osadzonych w tym polu rozważań, stanowiąc dla nich czynnik z jednej strony determinujący, z drugiej zaś organizujący - dlatego też można spojrzeć na przyzwyczajenie holistycznie, jak na zjawisko niezwykle złożone i wieloaspektowe.

Omawiane pojęcie, z racji wysokiego stopnia ogólności, uwikłane jest w sieć pojęć współwystępujących oraz zbieżnych znaczeniowo - można to zobrazować, wskazując chociażby takie pojęcia, jak nawyk, sprawność czy dyspozycja, z zastrzeżeniem, że podane przykłady z pewnością nie wyczerpują pełnej listy pojęć zbieżnych.

Podsumowując, można stwierdzić, że przyzwyczajenie stanowi niezwykle bogatą w znaczenia kategorię filozoficzną. $Z$ tego powodu winno być zawsze interpretowane w kontekście danej koncepcji, gdyż - jak starano się wykazać - można wskazać na wiele jego aspektów. W każdym z nich przyzwyczajenie związane jest z ważną sferą 
aktywności ludzkiej. Zagadnienie przyzwyczajenia niewątpliwie dotyka istotnego filozoficznie problemu kondycji człowieka.

\section{Summary}

\section{Philosophical aspects of process and effects of habituating}

This article describes philosophical aspects of the group of phenomena which are closely related to an English word "habit" and Latin habitus. The author uses a term "habit" when meaning a large set of effects of the process of habituating or accustoming in multiple descriptions - the following meanings seem to be the most popular: tendency, disposition, motor skill, unreflective/automatic behavior, attitude or mental state. The process appears in two different dimensions, as a habituation, it refers to a psychophysiological process of adaptation to constantly repeated stimulus, and as a habit formation, it usually refers to the formation of automatic response to stimulus in a behavioral sense. The author signalises a wide range of subjects mentioned in this article because all mentioned phenomena are included in the Polish term "przyzwyczajenie", which here is understood as a process or an effect of a process existing in the psychophysical sphere as a scheme, which is formed by a long-time repetition with a characteristic reduction of attention proportional to progression made in the learning process.

The main purpose of the research is to present that phenomena of the process and effects of habituating can be analyzed in a philosophical sense as an important category and described in ethical, epistemological, aesthetical and anthropological areas. The process and effects of habituating can be considered in reference to the problem of fundamental philosophical dichotomy like 'subjective vs. objective', 'empirical vs. rational' and 'relative vs. absolute'. They can also be described in the context of values - truth, goodness and beauty.

\section{Keywords}

Accustoming, habit formation, habituation, process of learning 